\title{
Effect of Coal Based Industries on Surface Water Quality of Singrauli Industrial Area of M.P. (India)
}

\author{
${ }^{1}$ Dr. Vinod Dubey, ${ }^{2}$ Neha Singh, ${ }^{3}$ Shalini Singh, ${ }^{4}$ Sonam Shukla, \\ ${ }^{5}$ Aparna Pandey \\ ${ }^{1}$ Professor, Applied Chemistry Division, Deptt. Of Chemistry, S.G.S. Govt. P.G. Autonomous (NAAC \\ Accredited) College, SIDHI-486661 (M.P.) India \\ ${ }^{2,3,4}$ Research Scholar, Applied Chemistry Division, Deptt. Of Chemistry, S.G.S. Govt. P.G. Autonomous (NAAC \\ Accredited) College, SIDHI-486661 (M.P.) India \\ ${ }^{5}$ M.Sc. Student of Deptt. Of Chemistry, S.G.S. Govt. P.G. Autonomous (NAAC Accredited) College, SIDHI- \\ 486661 (M.P.) India
}

\begin{abstract}
The impact of waste water discharge has been determined by analyzing the water sample with the help of the standard parameter. The result clearly indicates that the surface and ground water of the said area is being polluted substantially. To put a check on such a pollution. Industries should adopt alternative technology along with bringing awareness among the people of the concerned area

Key words: Surface water, Pollutants, Spectrophotometeric studies, Water quality Parameter (WQP). Central Pollution Control Board (CPCB), State Pollution Control Board (SPCB)

\section{Introduction}

The district Singrauliy is located in the north east part of Madhya Pradesh almost whole of the geographical area of this district is having rich coal belt and hence number of coal based industries have been set up in Public and Private sector both. This project work is undertaken as a case study to find out the impact of waste water discharges from coal based industries in the surrounding area (specially surface and ground water). For the assessment of water quality of the said area (12) twelve water samples were collected (04) four each from, NTPC Vindhyanager, Steel Plant Godwali Deosar and Hindalco Bargawan as per the norms laid by Central Pollution Control Board (CPCB). Various water quality parameters were studied and tests of the samples were carried out. The experimental investigations have been performed as per American Public Heath Association (APHA).
\end{abstract}

\section{Result and Discussion}

The results of different water quality parameter have been presented in Table-1.

Table 1: Water Sample Result

\begin{tabular}{|c|c|c|c|c|c|c|c|c|c|c|c|c|c|}
\hline \multirow{2}{*}{ No. } & \multirow{2}{*}{ Parameters } & \multicolumn{4}{|c|}{$\begin{array}{c}\text { NTPC Vidhyanagar } \\
\text { Singrauli }\end{array}$} & \multicolumn{4}{|c|}{$\begin{array}{c}\text { Steel Plant Godwali } \\
\text { Singrauli }\end{array}$} & \multicolumn{4}{|c|}{$\begin{array}{r}\text { Hindalco (Bragawan) } \\
\text { Singrauli }\end{array}$} \\
\hline & & $S-1$ & $S-2$ & $S-3$ & $S-4$ & $S-5$ & $S-6$ & $S-7$ & $S-8$ & $S-9$ & $S-10$ & $S-11$ & $S-12$ \\
\hline 1. & $\begin{array}{l}\text { Alkalinity } \\
(\mathrm{mg} / \mathrm{l})\end{array}$ & 75 & 79 & 109 & 132 & 103 & 104 & 300 & 190 & 240 & 200 & 198 & 235 \\
\hline 2. & $\begin{array}{l}\text { Ammonia } \\
(\mathrm{mg} / \mathrm{l})\end{array}$ & 0.6 & 0.5 & 1.2 & 1.9 & 0.7 & 1.28 & 4.9 & 3.9 & 1.1 & 1.3 & 1.5 & 1.2 \\
\hline 3. & Arsenic $(\mathrm{mg} / \mathrm{l})$ & 0.04 & 0.02 & 0.03 & 0.01 & 0.01 & 0.03 & 0.01 & 0.005 & 0.02 & 0.03 & 0.01 & 0.001 \\
\hline
\end{tabular}


Effect of Coal Based Industries on Surface Water Quality of Singrauli Industrial Area of M.P. (India)

\begin{tabular}{|c|c|c|c|c|c|c|c|c|c|c|c|c|c|}
\hline 4. & BOD (mg/l) & 13 & 14 & 12 & 15 & 10 & 11 & 12 & 16 & 29 & 26 & 28 & 25 \\
\hline 5. & Calcium (mg/l) & 28.3 & 32.7 & 37.9 & 30.3 & 29 & 28.5 & 18.8 & 48 & 78 & 75 & 70 & 72 \\
\hline 6. & Chloride (mg/l) & 41.2 & 106 & 43 & 104 & 61 & 102 & 122 & 90 & 122 & 129 & 132 & 125 \\
\hline 7. & $\operatorname{COD}(\mathrm{mg} / \mathrm{l})$ & 50 & 58 & 62 & 63 & 77 & 63 & 68 & 61 & 69 & 73 & 95 & 55 \\
\hline 8. & $\begin{array}{l}\text { Color } \\
\text { (Haz-en-unit) }\end{array}$ & $5 \mathrm{H}_{\mathrm{z}}$ & $10 \mathrm{H}_{\mathrm{z}}$ & $9 \mathrm{H}_{\mathrm{z}}$ & $6 \mathrm{H}_{\mathrm{z}}$ & $20 \mathrm{H}_{\mathrm{z}}$ & $10 \mathrm{H}_{\mathrm{z}}$ & $5 \mathrm{H}_{\mathrm{z}}$ & $19 \mathrm{H}_{\mathrm{z}}$ & $5 \mathrm{H}_{\mathrm{z}}$ & $6 \mathrm{H}_{z}$ & $7 \mathrm{H}_{\mathrm{z}}$ & $3 \mathrm{H}_{\mathrm{z}}$ \\
\hline 9. & $\begin{array}{l}\text { Conductivity } \\
\text { (Microsiemens) }\end{array}$ & 286.2 & 264.2 & 261 & 285 & 246 & 234 & 241 & 243 & 270 & 330 & 290 & 345 \\
\hline 10. & Fluorides (mg/l) & 1.6 & 1.5 & 1.0 & 1.4 & 3 & 0.6 & 1.8 & 1.9 & 1.5 & 1.8 & 1.6 & 2.2 \\
\hline 11. & Iron (mg/l) & 1.6 & 1.4 & 1.3 & 1.1 & 1.18 & 0.7 & 0.6 & 0.8 & 3.2 & 3.1 & 3.4 & 2.5 \\
\hline 12. & Lead (mg/l) & 0.03 & 0.02 & 0.02 & 0.01 & 0.03 & 0.01 & 0.01 & 0.04 & 0.05 & 0.06 & 0.06 & 0.08 \\
\hline 13. & $\mathrm{PH}$ & 5.9 & 8.3 & 5.8 & 8.4 & 7.1 & 7.0 & 7.3 & 6.8 & 8.8 & 8.7 & 8.6 & 8.9 \\
\hline 14. & TSS (mg/l) & 62 & 57 & 58 & 61 & 73 & 74 & 67 & 81 & 77 & 95 & 98 & 109 \\
\hline 15. & Turbidity (NTU) & 6.0 & 5.6 & 5.7 & 5.9 & 4.7 & 4.8 & 4.6 & 21.6 & 12.5 & 13.8 & 14.7 & 13.3 \\
\hline 16. & TDS (mg/l) & 155 & 154.8 & 141.4 & 142 & 133 & 132 & 129 & 136 & 109 & 111 & 119 & 110 \\
\hline 17. & Hardness (mg/l) & 285 & 760 & 283 & 765 & 1256 & 1257 & 1280 & 1517 & 281 & 279 & 269 & 266 \\
\hline 18. & Sulfate (mg/l) & 52 & 55 & 40 & 39 & 35 & 38 & 40 & 158 & 31 & 34 & 32 & 36 \\
\hline
\end{tabular}

The PH of all samples was within the limits. The turbidity of S-8 was highest among all the samples. The hardness value of S-8 was highest followed by S-7, S-6. The BOD of S-9 and S-11 were higher in comparison of other samples. The COD values were within the limits. The ammonia content of S-7 and S-8 was quit high. The Iron content of S-11 and S-9 was very high and the values exceeded the prescribed limits.

The arsenic (As) Iron $(\mathrm{Fe})$ and Lead $(\mathrm{Pb})$ content of different water samples (S-1 to S-12) may be observed from (table-1) that the arsenic contents ranged from 0.001 to $0.04 \mathrm{mg} / \mathrm{l}$ in the study area, the arsenic content of all water sample was within the limit. The prescribed limit of As is $0.2 \mathrm{mg} / \mathrm{l}$.

The Lead content varied from 0.01 to $0.08 \mathrm{mg} / \mathrm{l}$ in the study area the Lead content of S-12 was comparatively higher than the other water sample. The Lead content of all water sample was within the permissible limit the prescribe limit is $0.1 \mathrm{mg} / \mathrm{l}$.

After the careful study of the result it reveals that the water quality of water sample S-9, S-10, S-11 and S-12 with respect to alkalinity, aluminum, arsenic, calcium, color, COD and conductivity was meeting the desired criteria.

The sample S-9 had a very high BOD and S-8 and hardness value followed by S-11, S-10 and S-7, S-6. The water sample S-5 had a very high content of fluoride; S-8 had a high turbidity value, S-11 having high conductivity value, while S-10 Arsenic, S-11 Iron, and S-8 having highest value for hardness in comparison to 
other water sample. The water sample S-10 from Hindalco Ash pond and S-6 from steel plant and S-3 form NTPC Vindhyanager were comparatively more polluted than other water sample.

With alarming increase of surface water pollution in the study area it become very much essential for the M. P. Govt. and M.P. Pollution Control Board to control further pollution of the surface water and deterioration in water quality.

\section{Experimental}

Twelve water sample four each from NTPC Vindhyanagar, Steel Plant (Godwali) Deosar, and Hindalco Bargawan, were collected according to the norms laid by CPCB various water quality parameter were studied and their tests were carried out as per American Public Health Association. The various water quality parameter that were studied are as follows-

1. Physical Parameter: Color, Turbidity Odor, Total Suspended Solid, Total Dissolved solid and conductivity.

2. Metals : $\mathrm{Fe}, \mathrm{Ar}, \mathrm{Pb}, \mathrm{Al}, \mathrm{Ca}$, and Hardness

3. Inorganic Non-metallic Parameter: Acidity, Alkalinity, Chloride, Fluoride, PH and Sulfate.

4. Organic Parameters: BOD, COD, and Dissolved oxygen.

Atomic Absorption Spectrometric method for determination of Arsenic and Lead was adopted in which. An electrically heated atomizer or graphite furnace is used. A discrete sample volume is dispensed into the graphite sample tube; typically determinations are made by heating the sample in three stages-

1. A low current heats the tube to dry the sample.

2. Charging stage destroys organic matter and volatilizes other matrix components at an intermediate temperature.

3. Finally a high current heat the tube to incandescence and in an inert atmosphere atomizes the element being determined.

The resultant ground state atomic vapor absorb monochromatic radiation from the source, a photoelectric detector measures the decreased intensity of transmitted radiation which is a measure of concentration.

\section{Conclusion}

Due to rapid industrialization and modernization the coal based industries are increasing at an alarming rate. The Coal based industries, such as by product coke- plants, coal washeries and thermal power plants release their liquid effluents, which are needed urgent attention for the treatment before they are discharged into fresh water streams.

The impact of Fluoride pollution is severe in the belt of Bargawan, Waidhan and Deosar are of Singrauli district. Incidence of white spots, skin infections and lumps of dead skin has been reported among the population of study area. A high percentage of gastro-intestinal parasitic infection was also found in the fecal sample of cattle in the village affected by effluents from coal based industries and coal mining.

With alarming increase of surface water pollution it become very much essential for the M.P. Govt. and M.P.P.C.B. to Control Further Pollution. The C.P.C.B. and S.P.C.B. rules should be strictly implemented along with educating the concerned mass for taking appropriate precautionary measures.

\section{Reference}

[1]. American Public Health Association (APHA), 1985, Standards methods for examination of water and wastewater, 16th Edition, USA, Baltimore MARYLAND.

[2]. Baba, A., Kaya, A. and Birsoy, Y. K., 2003, "The effect of Yatagan Thermal Power plant (Mugla Turkey) on the Quality of surface and Ground water", Waste Water Air and Soil Pollution, Volume 14, Nos 1-4, pp. 93-111

[3]. Bishnoi, M. and Malik, R., 2008, "Ground Water Quality in Environmentally degraded localities of Panipat city, India, Journal of Environmental Biology, Volume 29, No. 6, pp-881-886

[4]. Central Pollutiona Control Board (CPCB), 2003, Water Quality in India status and trend (1990-2001), pp- 1-17

[5]. Junshum, P. Traichaiyapom, S. and Chunluchanon, S., 2004, "Water Quality at Mac Moh Power Plant Lampang Province", International Journal of Environmental science and Technology Volume 29, No. 2, pp-51-54

[6]. Parashar, C., Dixit, S. and Shrivastava, R., 2007, "Assessment of Possible impact of climate change in water reservoir of Bhopal with special reference to Heavy metals Central Region, India. Journals of Applied Science Environ. Manage, Vol. 11, No. 2, pp. 9193 